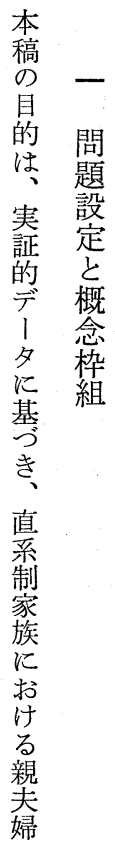

化我々 方济夫 向 直婦 を系間 示制 の 唆家 関

乙族係 てのの く内市 れ部り る 構 方 で造を あの明 万理 う解加 学に 考促要 え、 らさ れらに るに市 本 直 稿系こ で制の は家課 族 題 分市 析 変
象族機らるのに単内 で内に結得本内よ扮現位部本 は部、論た稿部うい代と構稿 なの家的もでのなて日し造の く親族にの用生問、本ての目 子の言でい活題核のの理的 家両内えある領に分家核解は 族世部ばるデ域接離族家を の代構、。1 変間造直分夕お守傾直にし系 形のが系析はいる向系求、制 に境子制の、て手が制めさ家 留界世家方山生が夫家、ら族 るを代族法梨じか婦族そにに 現明にはは県、り制かの、お 象確再限横東親を家ら分直 计 でに編ら断山夫、族夫離系る 西区成れ分梨婦集へ婦を制親 る別さた析郡と団の制検家夫 寸社生法勝子的転家討族婦 とるる活と沼夫役換族すのと い比こ領反町婦割をへる变子 え較と域覆にがと桑の。化夫 る的か、面おい関む過の婦 。安ら家接いか係徽渡方間 定、族法てな的候期向の しこ周に、る役と関 たの期よ三関割しあ示係 傾分段っ回係のてる唆の 向離階てっを二あいしあ で傾にい二も側るはてり あ向おる九つ面の両く方 るはい。六てにか者机を 。直て六い求否㤎る明 し系、年るめ併它 た制分、か、、存あか が家離一、直之寸 万に つ族の 九棌いるら求 ての傾七焦制う状、る 現晏を向年点家䦗態起考亡 在定示、沶学市济

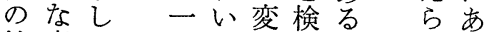
核変つ九た华討之れる 分化口 七分が市いる。

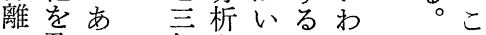
の据る年をか必れ本の 傾ん。試な要て稿課 向だしにみるがいで題 は傾かわる家ある は岕 家向した。放る。 族ば、っ周。る のか親て 期本こ 変り世実段稿て 質で代, 施階で をはの筆㨁 せな死 た 現家契查孞む家族族
直

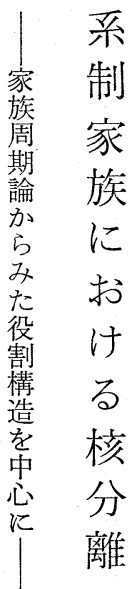

分我陌

析々 のに 単 直 位系工 
含と文よ期々が続のべ家同て在热族価的族て結こ単 さで的にあこあ、㐫族、存にる同居家は值継意婚こ位 まき諸、るるる家る的直続よ规を族区規承味後でを ざな条現いでい族た単系のっ婦直促は別賛さすをも直家 まい件在は、は内め位制基て制系守、さ範れる親系族 な。下の両現分部にの家本強家制外これをる新制的

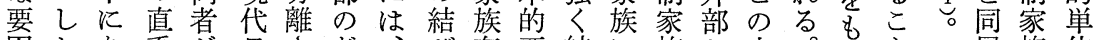

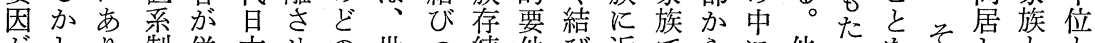
がしり、制併本せの世つ続件び近でらに他ずをれをとと 内、、家存のる生代きのがついもの含方、期れ、いし 包直か族守家か活をに基、い行、制委、一待は世うて さ系つはる族は領つあ本そて動そ度れ直時卞带のの れ制てこ状は、域なる的のい分の的る系的る具をは核 て家のれ態直をにぐ。要核る夕内規。制家体世、家 以族直ま汇系だお何し件家了部制家任族的代子族 るの系であ制十いらたはな族ンでが族意のに的供に か変制とる家分てかが、るをを親、の的こはにの求 ら化家はと族明世のつむ夫でも春一周にと家継うめ 、族異いから代手てし婦、つ婦般期住で名承ち、

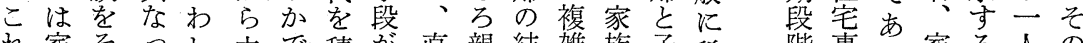
れ家そつれ夫で積が直親結雑族子稀階事り家る人の

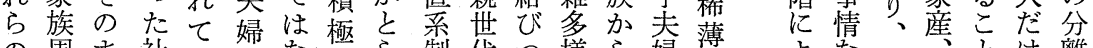

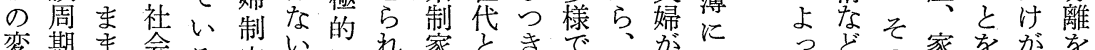
変期ま会る家いにれ家ときで、がにうどを家をがを 化段維的矛族結る族子に衣両明なってでの業理あ検

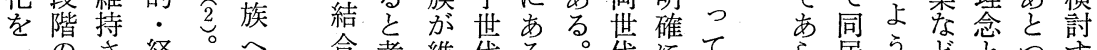
一のさ経。へ合考維代る。代にてら居うど う斿 様変せ済周のさえ持のの怔分き市なながすぎる。 論を华る的知過せら渡、るれ存っ比制居し現るる家念代家乞

るが、マ化化ら $\mathrm{A}^{\prime}$ 質がをこ不傾る。うる段う候際ず

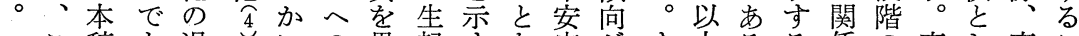
ここ稿も過しにの異起すな定がす上るる係の直し直こ こうであ程しす恋にしとくな強なの基こ起系て系と でし筆るをつる化すつい、家まおよ否ともい制あ制は

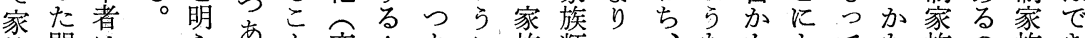
族問は ら市変 $\mathrm{A}$ あこ族類つ、なをよてな族の族き 的題、少型かるとの型つ直観いっいるのかにな

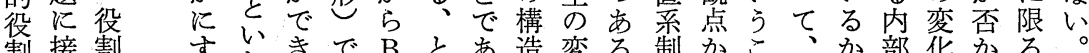
割接割すおきで B 々近構るおるあへいる的化と家らと現、のを、なま はす造省るでるのう境のす族方実に生よとらた 集るの 京市か変ここ界傾れに本での焦活りいば 団手領は本乃、华文を向ばお稿き直点領具引、い

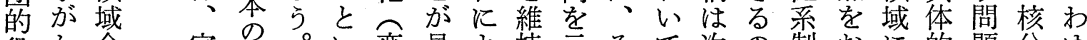
役か全家家。い変見上持示そて次の制おに的題分ゆ 割り体族族々っ質出っ守の、ので家いおにを離る とをを社族りた害して存核現よあ族たい捉看がる 関家問会現わ直 3 得、続か分実うるの分てえ過夫核 係族題学珼け系でた直さに離とな。内析、るす婦家 的的に状、制あな系せ、澺仮部が親にる制族 役役す課に直家るら家る別別識説 割割る せお系族かば族比居居のを

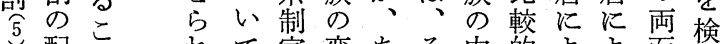

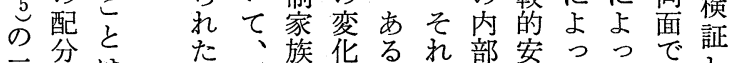
二分関は重そ等のいら構定ててでし 側係で要机質過はの造し分分核よ 面にきなら的程 $\mathrm{A}$ 恋にた裂裂分う

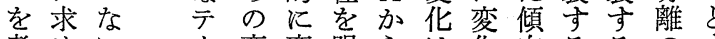
考めW I変変明らは化向るるのす

構必夫はこ家化 造要婦、文族 にでといもへの 変あ子かでの問 化る夫なき転題 が。婦るな換を 生まが家いを検 起たい族で丝討 し、か周あむす つそな期ろ徴る 
うてのるの心場

、文地さとで調 と調花域かな西查 推查之地 定地偠在なて、性 さ勝值必地 い果 る沼観ず域る樹山 るはがしで。载梨 そ玅々离こ境臬 のしいかよ蒙山 変つがらう世梨 化った、常郡 をあいこ、が勝 ある。こ高多沼

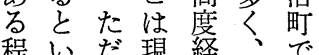
程わだ現経農市 受机近日成産る 活了時本長物。 止首、のの販勝 め都急平波売沼 や圈速均飞類町 す周な的ののは い辺勾なっ中甲 地の配農たで州 域豊で村商ぶぶ で村農を業どと 村村代的 う あと地表農がの 万乙域守業中本
をと分かにら世る二をわの成慮

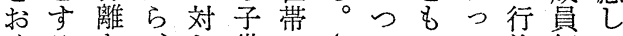
くるな、し世のさのつて為個て 二分。い親て代代ら家こお多い

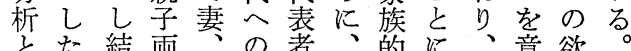
調とた結両舟の者、的飞、意欲。 查なが合世母役世単なよ味求こ るっの代飞割主代位るりすをれ の。ていの対移埊間のの影る充ら 対、か相し行者のかで響。足の 象本な互てのな分か、集守役 と稿る関子あど離わその団る割 方 でパ係とりの傾りの㐫的たは は夕飞い方役向あょる、め、

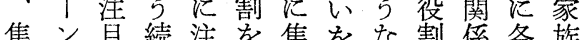
霜出唡自含点役的成全 的よた的し意をら割担役員体 役りい地たす据えに当割がを 割支。位いるえる注すはそ代 よ配こに。かるの目るいの表 り的こ基一らなにすすず地し もでで方方ららるの柆た 関市はく注估りこはもにり 係る、役関こ他勢応

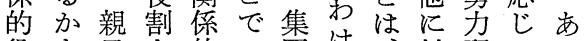
役を子を的は団け、対配てる 割見両含役親的有親し分行い に出世意割世役効とてとうは 力文代赛は代割で子勢か家 点与にる夫かはあ、少族

響てばプルる IIid IIgb IIgc 集族成九九成年三にに究 表、表、。品行。上七六員次で夫分よ上室本

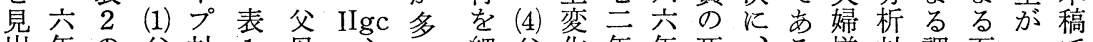
出年の父対 1 母公名細父化年年死、る揃対調面一で



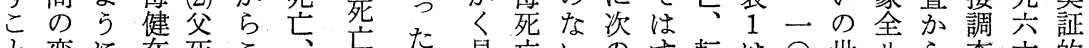

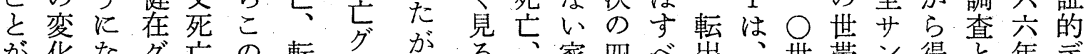
が化なグ亡の転ルか、る、家四心゙出、世帯ン得と年デ

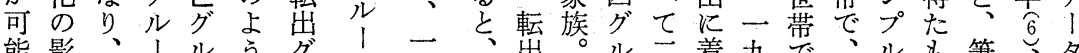
能影、1 ル

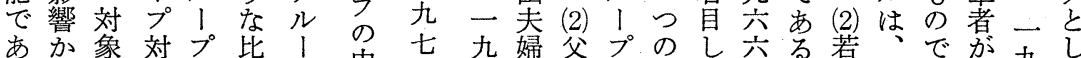
るら

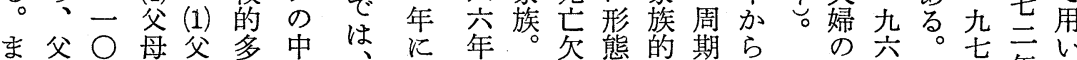
た死世死母いでIIhbはにさ損上単段一夫六三年る

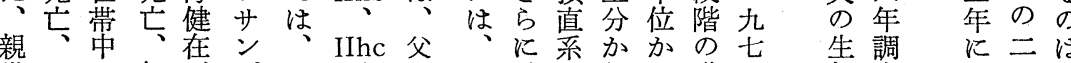
世母七転グプId、父、家れら進年香䒠回 代死一出ルルが健贯节族たな行年が時施飞東 の亡世グ、を多死在健ン族。っをま一にしわ景 死、带ルプ抽い亡 グ在プ (3) (1)て示で九、たた教 亡父々


ぞ死るで日、う।

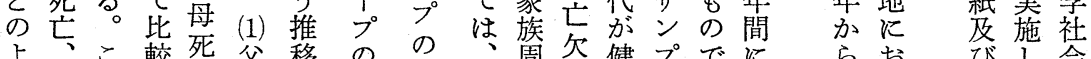

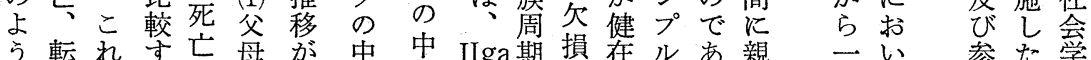

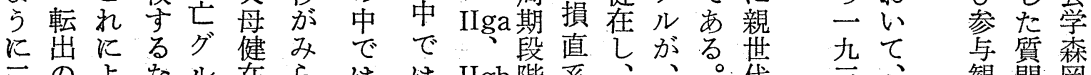
三のなル在らははIIgb階系、、。代严、観問岡 つ影っら1グれ 


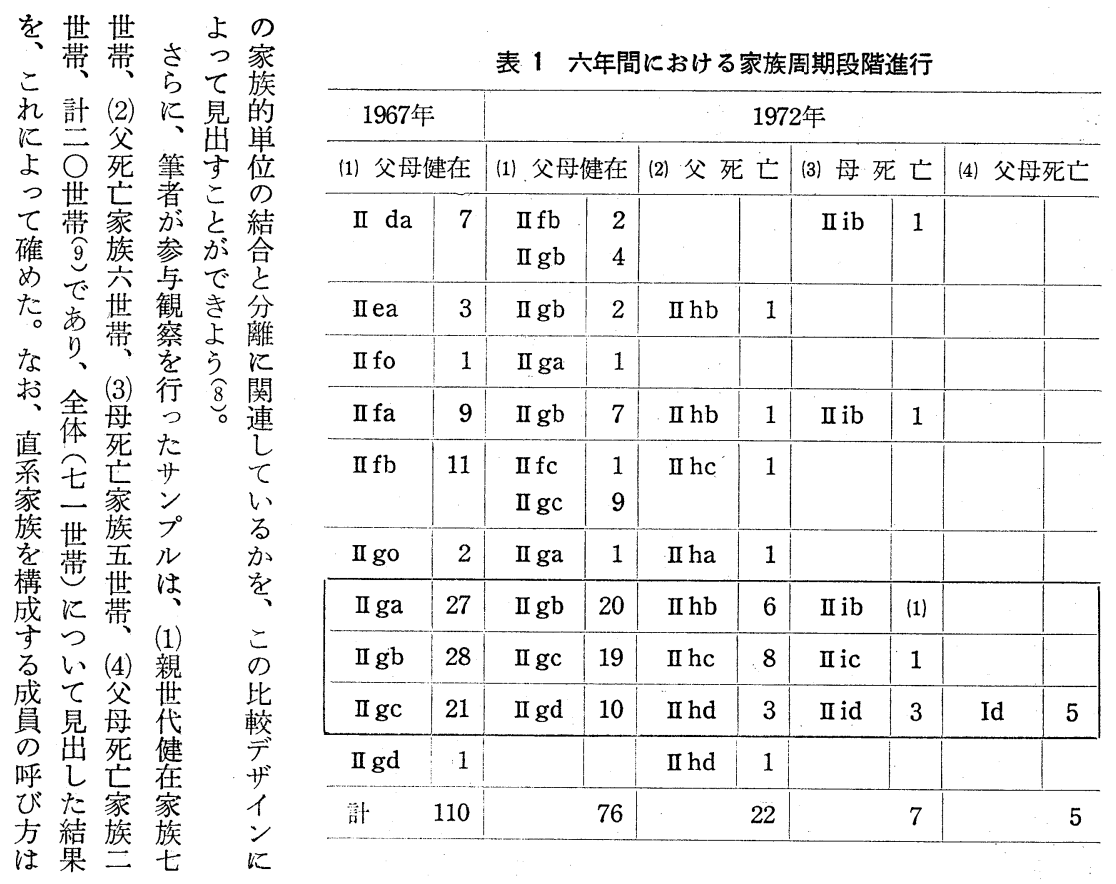

期期段た詳論が家せ家すつと時チで発のす程に族図 か、階いしにで族に族るててし間はあ達るる分尔と 1

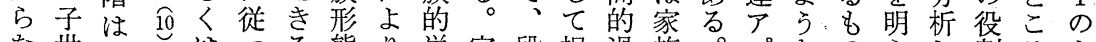

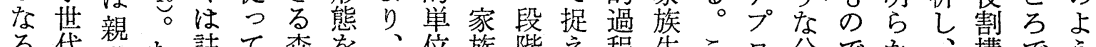
る代世た註て森を、位族階え程生こ分でか、構でう 三が代ををい岡捉さの周区るを活の、析あにそ造てで

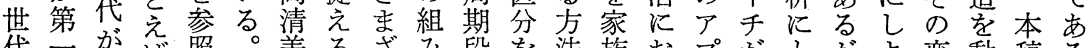
代一が照。美るざみ段を法族おプがとがよ変動稿る 夫教㩊、ささのこま合階設で周け口有っ、う华態は

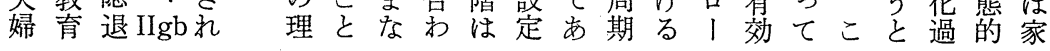

表 2 親世代健在家族グループと親世代 死亡家族グループの比較 (71世帯)

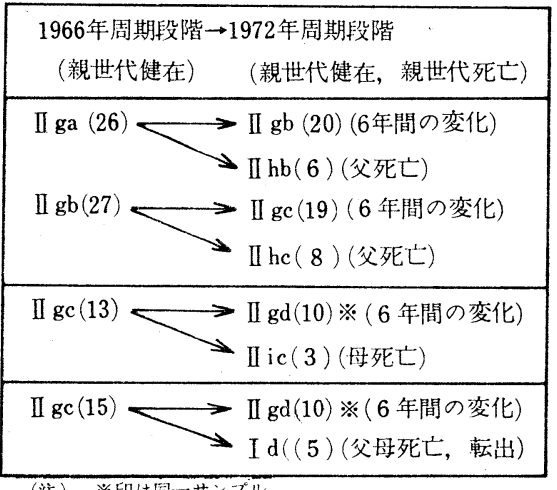

図 1

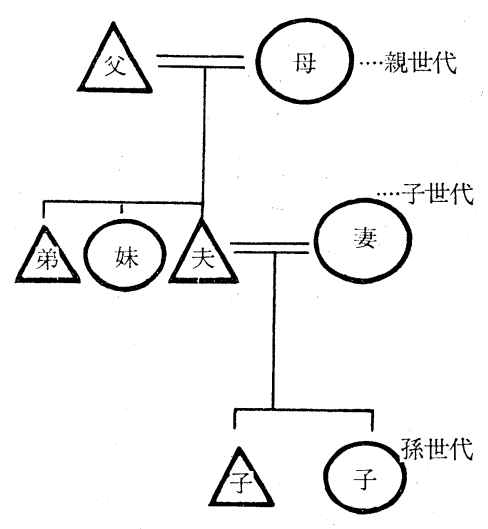




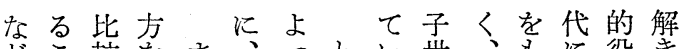

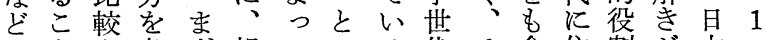
にとを各ず親てこる代そ含住割が本 関が通名、交行ながのめ宅はたの集 产でじル專子役でら住たた乺親結豊的 役るも 業世割豊両宅め家有親結家的

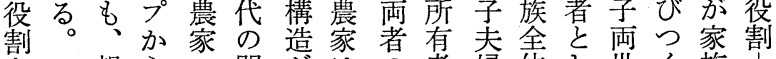
を一親らへ関がはの者婦体し世く族 親般世一七係か経閒でのをて代こ的 世代例七をな営にあ、プ自の間と小専 代、死今世年り面緊り、分管のに農業 加あ亡つ带ら相積張、イ達理関な単と らとに取しわ違の架親バ世的係る位兼 継らよりです导大高世愁代役の。で業 承ぎる出は役る小方代の割あそ存農 すで集しど割とにるはを管がりし在家

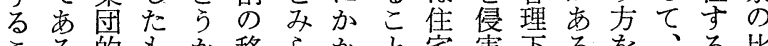

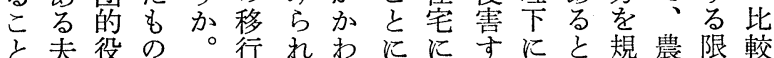
がは割で表をるるな関るあす定業り、 期、のあ 3 み 待資再るはて さ鹰編こ。 れ義を䐆的 位意る四割 座志程事 の に決度例 あ あ定みのり 集みこ兼永決れ衣ばる。産生 別いかあ識世との消 專就。らるを代えほ費

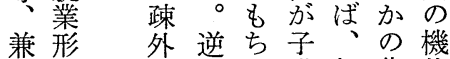

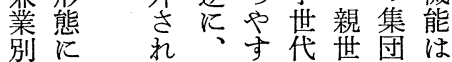
よで業な定も意親たそ文
を年一異同 組、側な居 み一面るの 三合九を段家 わ七分階族 家せ三析を形 族る年守発態 周技しる達に 法に横のお 期飞お断順け とょけ分序る 役っる析に段 割て反法つ階 構 い覆と皇を 造、る調、き示 の。查異あし 動かなわた らるせも 得時ての た点、で 横へそあ 断二のる 的九家。 情六族こ 報六群こ と年ので 縦、役の 断一 割 分 的九構析 情声造は
るIIgc産周 複る 場段意期 数。 合階志段存三 泥階 在 組 こ至定の守の のっは若る夫 段て周いこ婦 階夫期段と永 かは段階に揃 ら父階でなっ そ方夫るて の交進ががい 子代行父 人す寸農場 のるるら業合 譲。に取労 渡同従得钿 そ が時っしにれ 始にてて 関ら ま、徐い寸寸 る夫去る。主 あ夫ま割権 と㤎たはを

ぎか代専ち 方ら表業得 決取名農る ○得義家成 てし、゙員 い、資は唹
表 3 家族構成グループ別集団的役割の比較 （専業四事例）

（1972年）

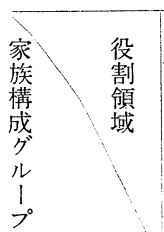

農業(ぶどう作)

農業以外の役割

農寄資資経支農営住世葬資資支消消 協合産鏟意出業農民帯式産住産出費費 頜出有志志行労簿 登名出有完志地決行 義席義定定為働記録義席義定為定為

\begin{tabular}{|c|c|c|c|c|c|c|c|}
\hline $\begin{array}{c}\text { 父 } \\
\text { 贯 } \\
\text { 健 } \\
\text { 在 } \\
\text { (II gb) }\end{array}$ & $\begin{array}{l}\text { 父 } \\
\text { 母 } \\
\text { 夫 } \\
\text { 妻 }\end{array}$ & $\begin{array}{l}\bigcirc \bigcirc \bigcirc \triangle O \\
\bigcirc \triangle O \bigcirc\end{array}$ & $\begin{array}{l}\bigcirc \bigcirc \\
\triangle\end{array}$ & 0 & 0 & 0 & $\begin{array}{lll}0 & 0 \\
0 & 0 & \\
0 & 0 \\
0 & \end{array}$ \\
\hline $\begin{array}{c}\text { 虍 } \\
\text { 点 } \\
\text { (II hc) }\end{array}$ & $\begin{array}{l}\text { 母 } \\
\text { 夫 } \\
\text { 妻 }\end{array}$ & $\begin{array}{l}000000 \\
\triangle\end{array}$ & $\begin{array}{l}\triangle 0 \\
\triangle 0 \\
\end{array}$ & $\begin{array}{l}\bigcirc \\
\triangle\end{array}$ & 0 & $\begin{array}{l}0 \\
0\end{array}$ & $\begin{array}{r}0 \\
0 \\
\end{array}$ \\
\hline $\begin{array}{c}\text { 母 } \\
\text { 死 } \\
\text { (II ib) } \\
\end{array}$ & $\begin{array}{l}\text { 父 } \\
\text { 夫 } \\
\text { 妻 }\end{array}$ & $\bigcirc \bigcirc 0_{\triangle}^{\Delta O} \bigcirc \bigcirc$ & $\begin{array}{l}O 0 \\
\triangle\end{array}$ & $\begin{array}{l}\bigcirc \\
\triangle\end{array}$ & 0 & 0 & ${ }^{\circ} \mathrm{O}$ \\
\hline $\begin{array}{l}\text { 父死 } \\
\text { 母亡 } \\
\text { (Id) }\end{array}$ & \begin{tabular}{|c|} 
夫 \\
妻 \\
亡父
\end{tabular} & $\begin{array}{c}00000 \\
0\end{array}$ & $\begin{array}{l}000 \\
\triangle\end{array}$ & 0 & $\begin{array}{l}0 \\
0\end{array}$ & 0 & 00 \\
\hline
\end{tabular}

（注） $O$ : 主要担当者, $\Delta$ : 補助担当者。 
の培にいて年と業こ進見段 変で従る。齢にととん出階次 华は事。周 11 むいにですの流

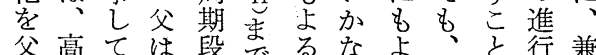
の度い息階農。るるなは業 みなる子染し職がおでし農 で技たっ進番か種、父きた家 は術め夫行主し家がながこ 受や、睢、組計担いっ三 け知農にて迸こ合の当。て 止識業そも集こせ主し住、世

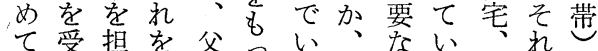
い沙当譲はてえな担る宅らに く大せり農いるどい。地のつ これざた業る兼に手この役い とるるく経す業よとれ所割て が柔をて営と農っなは有をは で軟得も注家てるサ名父、 き性な、携うの、成ン義と四 ながい息わこ特役員 プ 夫 5 い要。子り之徽割は心図間? 場求しつ、での構誰数 7 で 7 合さか夫そあ一造か加し交の がれししれるつ艻、少は代よ 多る、がに。は相㐫な周すう いたぶ他従し、違るい期るに 。めどの事た父导いと段過、 こ、う職しが齐るはい階程周 のこ栽業てっ高こ農うがを期

る日業 $d$ るるつ世 常労段なな。○て带こ の衝階おつそた、主の 財にに、たれと親名よ 布関至図よはえ世義う にすっ表うほぼ代、な 関るてでにぼ、か住 寸役、は、 $\mathrm{x}$ 図 る割妻示父曲 2 子、業 決をはしが線を世宅の 定分補て死亡見代地集 や担助い亡なるへの団 支す的なしつ移資的 出る担いてて、行産役 行。当がもあ父市所割 為まと、ならとる有の のたは夫おお夫過名う よ、いの資れが程義ち う結え生産る(5) をが な婚、産所。 IIgc示、農 家之夫活有し之去協 事 同と動 名 加(6) と期 組 的時同 が義しIIgd 2 段 合 役に様充は、の?階員 割、に実父表間 4 の名 を妻、しに3で図進義 取 は積て 残か交の行 得母極くるら代よに住 しか的る。明し うし民 てらにc らてにた登

よ分元かはす世所るも係域称いこ農し間は場

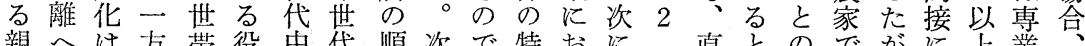
親へは方带役中代順次で特おに直とのでがに上業 世とみのの割心中ににあ徽け、関系み中はっかの若 代変ら世中がの心高、るをる個係制るに、てかこりい の化れ代心ほ比のいつ。み担人的家こ專交わをも子 小乙な飞的と率比。く両て当的役族々世業代るか父世 遣たい存財んが率一ろ世み者サ割をも代農さ集ら子代 い点が在布ど高が九い代よと、担維で的家れ団、協も 源は、すの子く高六も分ら受ビ当持き非のる的専同担 が注小るあ世なく六の離。益ス㔯存る連よさ役年で当 大目遣、り代っ、年をの表者、夕続。続うれ割兼遂导 幅にいとかへて二にす比 4 の消、さ換をになは業行る 飞值のみと移い九おる率は関費ンせ言直一い、農すむ

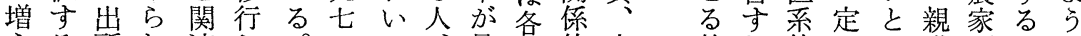
える所れ連し。三て、最領的支就れ的のい世別こに た。のるがたこ年、よも域役出業ばに段う代にとな ここみ。深このに支そ高別割金

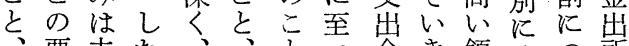

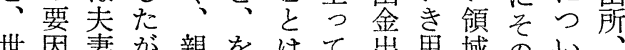
世因妻が親をはて出用域のい

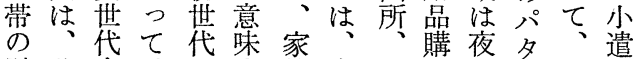

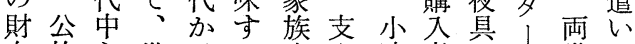
布的心世子る生出遣者のン世の が扶 带世。活金い後华出 子助変の代まの出の小片 12 間㫹 世华財のた運所出遣うをのの 代年せ布ど、営は所いけ示相生 へ金すのちこに夫はのでし互活 移に、多られ関妻父出あた関領 形、連階大か比にり 態専続できら較な で業さこな子导る。農 あ農せれ相世る。業 る家なら違代と、 に とは要役見周農㔔 心兼割出期業尔 え兼をるさ段生、る る業内交机階産集 農包代たの主団 家さ乙。進直的 よせな兼行接役 
図 5 兼業農家, 農協組合員名義（1972年） 図 2 専業農家, 農協組合員名義（1972年）
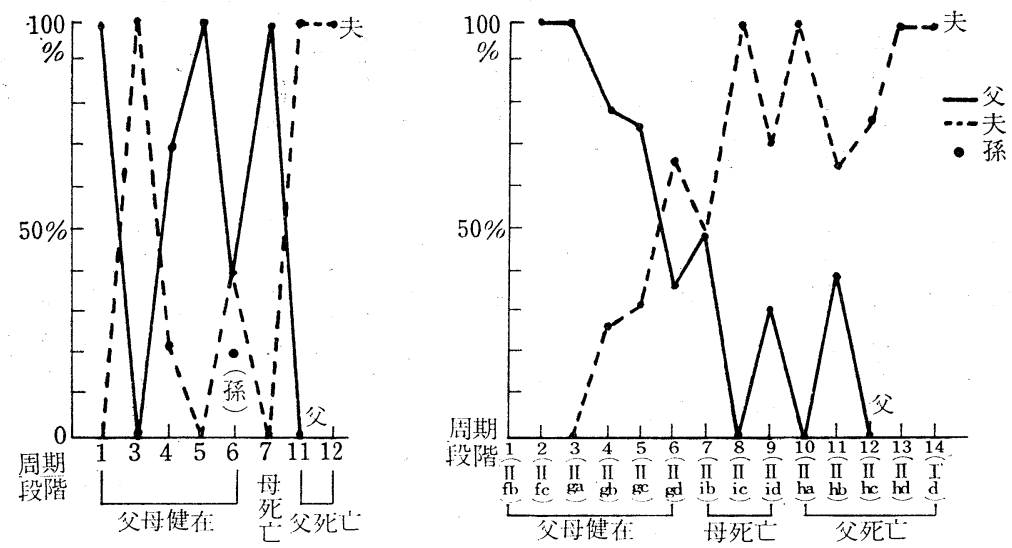

図 6 兼業農家, 住民登録世帯主名義

図 3 専業農家, 住民登録世帯主名義（1972年）

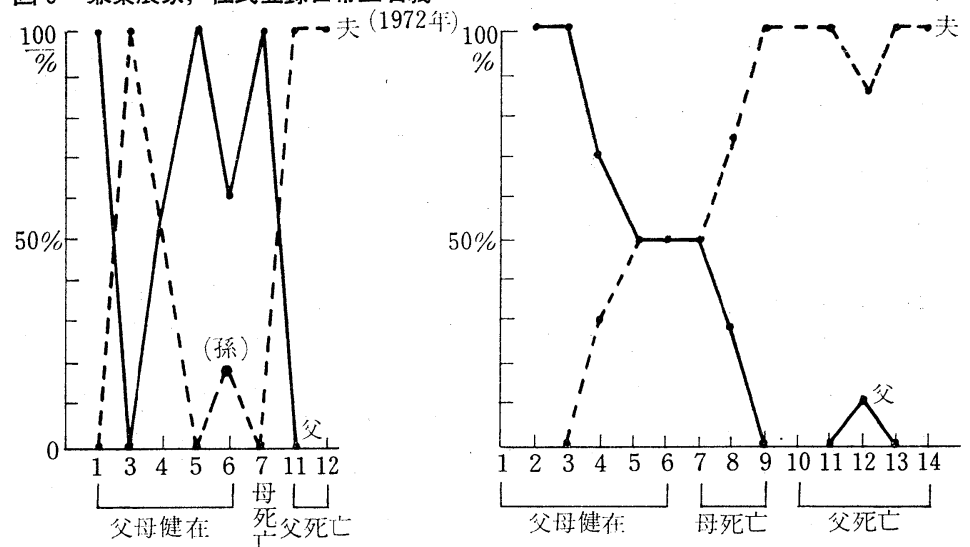

図 7 兼業農家, 資産所有名義（住宅，宅地）図 4 専業農家, 資産所有名義（住宅，宅地）



(1972年)




表 4 生活領域別関係的役割担当パターン（1966年，1972年）

\begin{tabular}{|c|c|c|c|c|c|c|c|c|c|c|c|c|c|}
\hline \multirow{2}{*}{$\begin{array}{l}\text { サービス, 財の } \\
\text { 出所, 項 } \\
\text { パターン }\end{array}$} & \multicolumn{2}{|c|}{ 洗たく } & \multicolumn{2}{|c|}{ つくろい } & \multicolumn{5}{|c|}{ 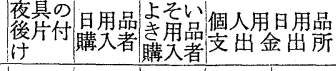 } & \multicolumn{2}{|c|}{ 個人用占そ心さ点出金出所 } & \multicolumn{2}{|c|}{$\begin{array}{l}\text { 個人用小遣 } \\
\text { 心の出所 }\end{array}$} \\
\hline & 1966 & 1972 & 1966 & $|1972|$ & $\mid \begin{array}{l}1972 \\
192\end{array}$ & 1972 & 1972 & 1966 & 1972 & 1966 & 1972 & 1966 & 1972 \\
\hline a 父母世代中心 & 2.7 & 0.9 & 5.5 & 7.3 & 0.9 & 7.3 & 4.6 & 45.9 & 14.8 & 54.2 & 19.3 & 55.1 & 21.1 \\
\hline b 夫妻世代中心 & 51.4 & 61.5 & 35.8 & 36.7 & 16.5 & 46.8 & 33.0 & 16.5 & 53.2 & 18.4 & 52.3 & 6.4 & 29.4 \\
\hline c 雨世代分髉 & 20.2 & 29.4 & 44.0 & $47.8 *$ & 73.4 & 35.8 & 42.2 & 27.5 & 22.9 & 22.9 & 21.1 & 21.1 & 41.3 \\
\hline $\mathrm{d}$ 個 人 的 & & & & & 7.4 & 8.2 & 18.4 & 1.8 & 5.5 & 0.9 & 5.5 & 0.9 & 0 \\
\hline $\mathrm{e}$ 協 同 的 & 23.9 & 8.2 & 14.7 & 7.3 & 0.9 & & 0.9 & 7.3 & 2.7 & 2.7 & 0.9 & 14.7 & 8.2 \\
\hline $\mathrm{f}$ そ の 他 & 1.8 & & & 0.9 & 0.9 & 1.9 & 0.9 & 0.9 & 0.9 & 0.9 & 0.9 & 1.8 & 0 \\
\hline 計 & 1 & & & & & & & & & (109) & (109) & & 00 \\
\hline
\end{tabular}

（注）*印\%調整。

日合しル領たをグし親めしン

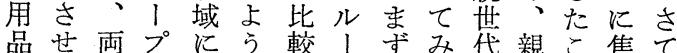
吱て世はおに俥プ第文死世新こ焦て

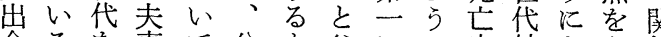
金るを事て分々父に親世きにのるれと

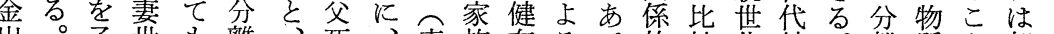

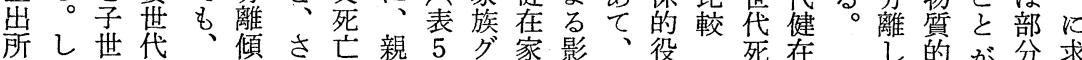
にか代中父向き家世参ル族響親割 お.中心死のの族代照 ! グを世担 い、心心亡あ表グ健等プル自代当 て個へへ家る 4 ル在 人再変族生で 1 家 親用統化 グ活み プ族
を 1出が パ

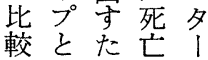

3 こ足た浸ら行 がた個を、た L的 $\tau$ 精 で的め い神で経ら る的き済れ と欲る分る 見求。離。

若ど特よるのを比比い死個に契母子夕る離て世

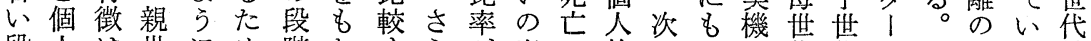
段人は世階た方らが出は的にかに代代ンこパる健 階的図代な、性らるに高所そサ親か夫中のはの夕。在 にサ 8 健る子供第子文くのれ、世わ妻心若父こ1一家 多l在。供第の、親な領らビ代ら世かい母とン方族 くビ 10 家しが至で父世る域のス健ず代ら段世かが、グ

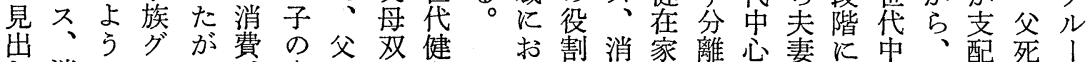
し消にルっ高方在い費族のへ世抋個的亡プ

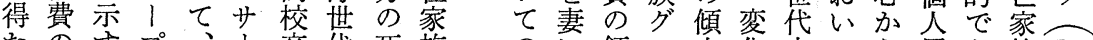
たのす プ、! 卒代死族の領こ領ル向花中てら角あ族IIga

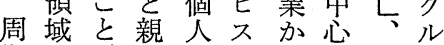
期飞が世的なら㤎転 |

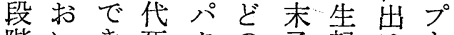
階いき死夕の子起はと がてる亡、領がす当公 進、。家ン域成る然母 行核こ族が注こ一死

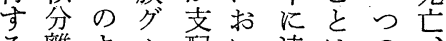
る離よル配い達はの、 にはう1的て守な家転 乙三飞プ た夫、のな自ま。的家 が婦旦比る分でた単族 つ揃用較。自のだ位グ てっ品か身段会ル

て購らで階子の 父父得す湾プ 母るなたる婦花を

み代域、をす心父夫支っグよ 高替のプ強る。变捿出たルIIgb るさ担㐫めて变死世金代出そプで がる者死いか导を中所れ

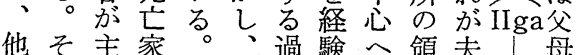
ののに族 小程し変域妻 IIhb世 領た母グ遣にた化で世案帒 域め心分家守は代は中 で、妻 1 の離族る、中で心 は分でプ 出へグすサ心すか 夫離あを㫹傾ルとンへでら 妻のる比のき! みプ変に分 世傾た較みみプら六離 代向め导 中は、る父死はる体し前変

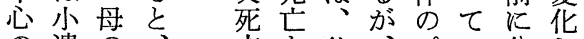

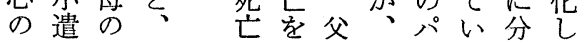


表 5 家族構成グループ別関係的役割担当パターンの変化 (1966年, 1972年)

\begin{tabular}{|c|c|c|c|c|c|c|c|c|c|c|c|c|c|c|c|c|c|}
\hline & \multirow{3}{*}{$\begin{array}{l}\text { 役割領域 } \\
\text { 年 次 } \\
\text { 周期段階 }\end{array}$} & \multirow{2}{*}{\multicolumn{2}{|c|}{\begin{tabular}{|c|}
$\begin{array}{c}\text { 日用品㗕入 } \\
\text { 担当者 }\end{array}$ \\
1972 年 \\
\end{tabular}}} & \multirow{2}{*}{\multicolumn{2}{|c|}{\begin{tabular}{|c} 
よそいきのもの \\
購入担当者 \\
1972 年
\end{tabular}}} & \multicolumn{4}{|c|}{ 個人用日用品金出所 } & \multicolumn{4}{|c|}{ 佃人用よそいき金出所 } & \multicolumn{4}{|c|}{ 個人用小遣心出所 } \\
\hline & & & & & & $1966-$ & 972 & 1966 & 1972 & 1966 & 1972 & $1966 \rightarrow$ & 1972 & 1966 & 1972 & & $6 \rightarrow-1972$ \\
\hline \multirow{16}{*}{ 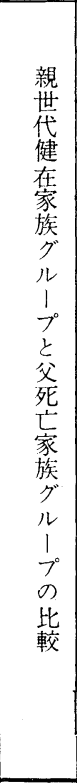 } & & Ilgb & Ilhb & Ilgb & Ihb & IIga & $I g b$ & IIga & $\mathbb{H h}$ & IIga- & $I_{g b}$ & $\operatorname{lgg} a$ & Ihb & Ig a- & $\| \mathrm{lgb}$ & IIga & Ihb \\
\hline & & 10.0 & & 5.0 & 16.7 & 50.0 & 30.0 & 16.7 & & 70.0 & 35.0 & 33.3 & & 75.0 & 30.0 & 66.6 & \\
\hline & $\mathrm{b}$ 夫妻世代中心 & 20.0 & 83.3 & 15.0 & 33.3 & 15.0 & 25.0 & 16.7 & 83.3 & 15.0 & 30.0 & 33.3 & 83.3 & 5.0 & 10.0 & & \\
\hline & $c$ 両世代分離 & 65.0 & & 75.0 & & 25.0 & 40.0 & 33.3 & & 10.0 & 35.0 & 33.3 & 16.6 & 5.0 & 50.0 & 16.7 & 83.3 \\
\hline & $\mathrm{d}$ 個人的 & 5.0 & 16.7 & 5.0 & 33.3 & & 5.0 & 16.7 & & & & & & & & & \\
\hline & $\mathrm{e}$ 協同的 & & & & 16.7 & 5.0 & & 16.7 & 16.7 & & & & & 10.0 & 10.0 & 16.7 & 16.7 \\
\hline & $f$ その他 & & & & & 5.0 & & & & 5.0 & & & & 5.0 & & & \\
\hline & (事例数) & 20: & (6) & 120 & 6) & 2 & 0 & 6 & & 2 & 20 & 6 & 6) & 2 & 20 & & (6) \\
\hline & 周期段階 & IIgc & Ilhc & $\mathrm{Ilgc}$ & Ilhc & $\operatorname{lgg} b$ & $I g c$ & $\lg b \rightarrow$ & Ihc & Ilgb- & Ilgc & $\operatorname{lgg} \rightarrow$ & Ilhe & Ilgb- & Ilgc & & $\rightarrow$ llhc \\
\hline & a 父母世代中心 & 5.3 & & & & 63.2 & 5.3 & 37.5 & & 63.1 & 15.7 & 50.0 & & 57.9 & 5.3 & 37.5 & \\
\hline & $\mathrm{b}$ 夫妻世代中心 & 57.9 & 62.5 & 36.8 & 62.5 & & 68.3 & 25.0 & 87.5 & 5.3 & 68.4 & 12.5 & 87.5 & 5.3 & 42.1 & 12.5 & $5 \mid 37.5$ \\
\hline & $\mathrm{c}$ 而世代分離 & 31.5 & 25.0 & 42.1 & 12.5 & 26.3 & 15.8 & 25.0 & 12.5 & 26.3 & 10.5 & 25.0 & 12.5 & 5.3 & 52.6 & & 50.0 \\
\hline & $\mathrm{d}$ 個人的 & 5.3 & 12.5 & 21.1 & 25.0 & & 5.3 & & & & 5.3 & & & & & 12.5 & \\
\hline & $\mathrm{e}$ 協同的 & & & & & 10.5 & 5.3 & 12.5 & & 5.3 & & 12.5 & & 26.3 & & 37.5 & 512.5 \\
\hline & $\mathrm{f}$ その他 & & & & & & & & & & & & & 5.3 & & & \\
\hline & (事例数) & $\mid 19)^{2}$ & (8) & (19) & (8) & \multicolumn{2}{|c|}{ (19) } & 18 & & & 19 & 18 & 8 & & 19 & & 8 \\
\hline & 周期段 & $a^{a}$ & Iid & Igd & Ilid & $\operatorname{Igc}_{-}$ & Ilgd & $\operatorname{Igc}$ & II id & $\operatorname{Igc}$ & IIgd & $\operatorname{Igc}$ & Ilid & IIgc- & $\| \operatorname{lgd}$ & Igge & $\rightarrow$ Ilid \\
\hline $\begin{array}{l}\text { 親母 } \\
\text { 世死 }\end{array}$ & 父母世代口 & 10.0 & & & & 30.0 & 10.0 & 33.3 & & 30.0 & 10.0 & 33.3 & & 40.0 & 10.0 & 33.0 & \\
\hline $\begin{array}{l}\text { 帒亡 } \\
\text { 健家 }\end{array}$ & 夫妻世代中心 & 60.0 & 66.7 & 40.0 & 66.7 & 20.0 & 60.0 & 66.7 & 100.0 & 40.0 & 60.0 & 66.7 & 100.0 & 10.0 & 20.0 & & 33.3 \\
\hline $\begin{array}{l}\text { 在族 } \\
\text { 名 }\end{array}$ & $\mathrm{c}$ 再世代分 & 20.0 & & 40.0 & & 20.0 & 10.0 & & & 10.0 & 0.0 & & & 20.0 & 70.0 & 33.3 & 366.7 \\
\hline ルル & $\mathrm{d}$ 個人的 & & 33.3 & 10.0 & 33.3 & & 10.0 & & & & 10.0 & & & & & & \\
\hline $\begin{array}{l}7070 \\
70\end{array}$ & $\mathrm{e}$ 協同的 & & & & & 20.0 & & & & 10.0 & & & & 30.0 & & & \\
\hline 毕 & $\mathrm{f}$ その他 & 10.0 & & 10.0 & & 10.0 & 10.0 & & & 10.0 & 10.0 & & & & & 33.3 & \\
\hline & (事例数 & (10) & (3) & (10) & (3) & (10 & & 13 & & & 10) & 3 & 3) & (1) & 10) & & (3) \\
\hline & 周期段階 & Igd & $\mathrm{Id}$ & Igd & Id & $\operatorname{llgc}$ & $\| \operatorname{lgd}$ & $\operatorname{lgc}$ & Id & $\pi g c-$ & $\operatorname{llgd}$ & $I_{g c}$ & $\rightarrow$ Id & IIgc- & Ilgd & $I_{g}=$ & $\rightarrow$ Id \\
\hline $\begin{array}{l}\text { 親父 } \\
\text { 世舟 }\end{array}$ & a 父母世代中心 & 10.0 & & & & 30.0 & 10.0 & 20.0 & & 30.0 & 10.0 & 20.0 & & 40.0 & 10.0 & 20.0 & \\
\hline $\begin{array}{l}\text { 䒫死 } \\
\text { 健亡 }\end{array}$ & $\mathrm{b}$ 夫妻 & 60.0 & 60.0 & 40.0 & 40.0 & 20.0 & 60.0 & 40.0 & 60.0 & 40.0 & 60.0 & 60.0 & 40.0 & 10.0 & 20.0 & 20.0 & 0100.0 \\
\hline 在家 & $c$ 而世个 & 20.0 & & 40.0 & & 20.0 & 10.0 & 40.0 & & 10.0 & 10.0 & 20.0 & & 20.0 & 70.0 & 60.0 & \\
\hline 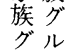 & $\mathrm{d}$ 個人的 & & 40.0 & 10.0 & 60.0 & & 10.0 & & 40.0 & & 10.0 & & 60.0 & & & & \\
\hline $\begin{array}{ll}\pi & 1 \\
1 & 7\end{array}$ & e 協同的 & & & & & 20.0 & & & & 10.0 & & & & 30.0 & & & \\
\hline $\begin{array}{l}70 \% \\
\xi \cdot \text { 比 }\end{array}$ & $\mathrm{f}$ その他 & 10.0 & & 10.0 & & 10.0 & 10.0 & & & 10.0 & 10.0 & & & & & & \\
\hline & (事例数) & (10) & (5) & (10) & (5) & (1) & & 5 & & & 10) & $(5)$ & 5) & & 10) & & (5) \\
\hline
\end{tabular}

（注）森岡清美『家族周期論』培風館，1973，315頁参照。 


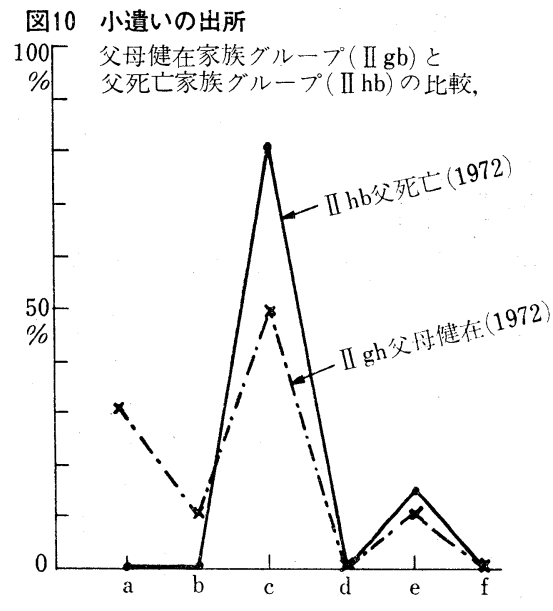

図11

個人用支出金出所

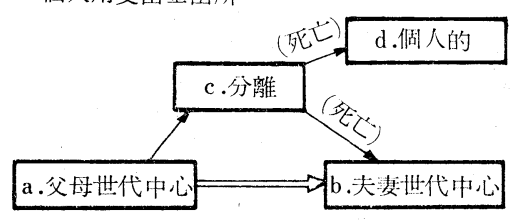

個人用小遺いの出所

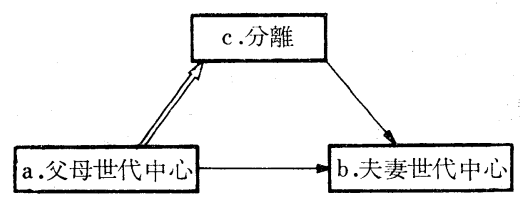

図 8 個人用品支出金出所の変化 $(1966 \rightarrow 1972)$

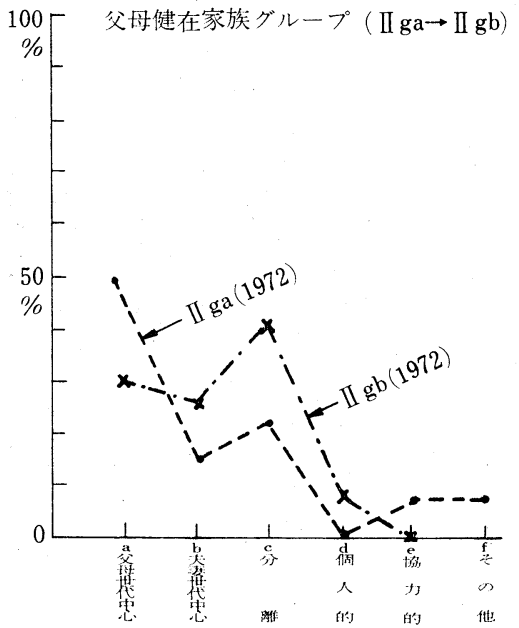

図 9 個人用日用品購入担当者 (1972年)




にが々やよの献れ

子同に心う世立は

世二献父に代を二

代献妾向両好分事食出罂てこ変転さ分

あ立作体世棸て例活時部検の化出ま離

るをる体がいす。の屋討グすあざと

こと都架違る心゙直結としルるるす家

とると都納

が事い合得たそに制つのうプそは社内

確例う上しめの幏き掃。ごこ出会人

認に母胥て、理 $儿$ 族

さつ死畕分双由ての

れい亡悪け方は見特

たて家墨ての、出徴

た、族いい世公さの

めさの胃る代㕮れ-

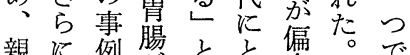

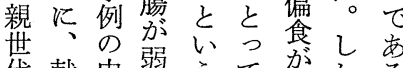

代献中弱方台方る

の立に心親好でし同

か決出妻代きあこ食

ら定さ唯健なり、の仝

み権れ父在食氺

る、るの家事さちつ

之遂。た族がら五い

次行両めのでに事て

の芯に事き双例

三主代別例る方㤎そ
り活態区ミの

、別 $ッ$ 死家 1 るせらン代 比るかが中

四較傾で増心 的向あ加

家安をるす分

族定示。る離

構た壮をこ減

成過かあの少

グ 程り兑こし

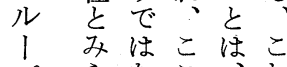

(3) 等抽父よ外䦕 プらなこは犯 子る出母う在 供指乙のな的 の標た健内要 教 は三在在 因 育次 $\bigcirc$ 的を の事 死 要 受

(4) 六例亡恩计 看項をにに止 病自中よ触め、 (5)で心さ発さ 情あ四京ら 緒る核グつに 的。分ルつ家 W(1) 離 | ダ 族 た食のプイ成 わ生実をナ員
別れくで図に

核る。の 11 代

分资分でわ

離段性して

傾階三た夫

向 へ個妻

のの人世

移核用代

行家支中

を族出心

石的 金

厶 単出個

I 位所人

无をか的

に分らパ

さ裂もタ

ではの供供は除掃孫る両プ、りを族にルけ緒分かつ

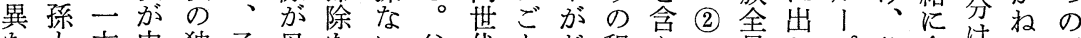

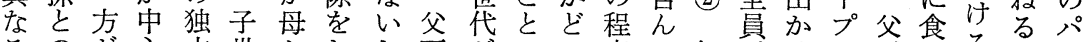
るのが心立世㠰しし死がにの度で個がけでが心゙るのタ 結死とに代らて他亡部分程空い人出なは死たこで। び亡なとと妻い出家屋離度間る部かい子出いと、、

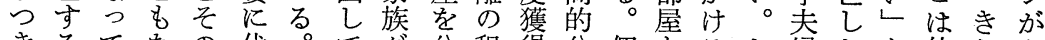
きるてなの代。てグ分程得分個とるし婦たと仲らあ

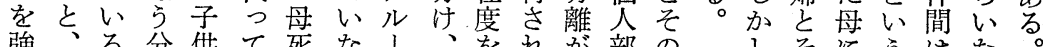

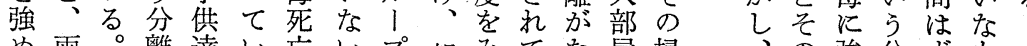
め、両。離達い亡心プ親みてな屋掃、の強分すすすり 、世こでとる家傍で世るいさが除親子い離れのま 父代のあの。族采は代交る机な。世供。否のはり はの領る明父グ成、代、かていこ代達ま定よ避 妻結域が確母ル員部は親、いのこの染た的う活本

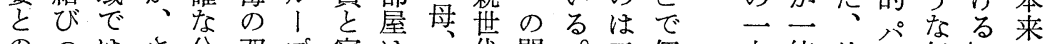
のつはさ分双プ寝は子帒問。文個方緒外タ気よな 結き分ら離方で起両子健題こ○人分に食タ持とら びが離にががもき世世在にの事部死出を|年いい分

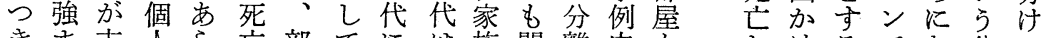
きま支人ら部てには族関離中と部々けるでな分て るる配部わ乞屋部分妻グ連は主は年る際ある離欲 強。的屋れたは屋か加ルし、例夫 めたでのて家分をれ掃 |て個の婦 るだあ掃い族けとて除プい人み部 点そる除るグてもいをでるので屋

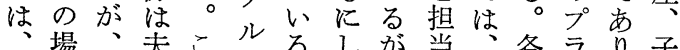

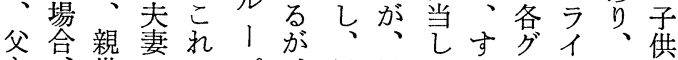
と、世のはプ、母母てぶルバか部 母母代子子で掃架はいて| シな屋 家が、るた肯し 族、親。め定 グ 親夫後、的 が ル夫婦者同パ、 、婦健はじタそ プと在、献、れ では家と立ンも は家緒グわ族りをとで 
六参故任しとし任

夫夫照に (4) ぜ農答た艺

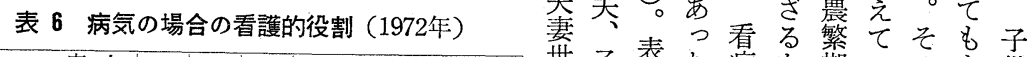

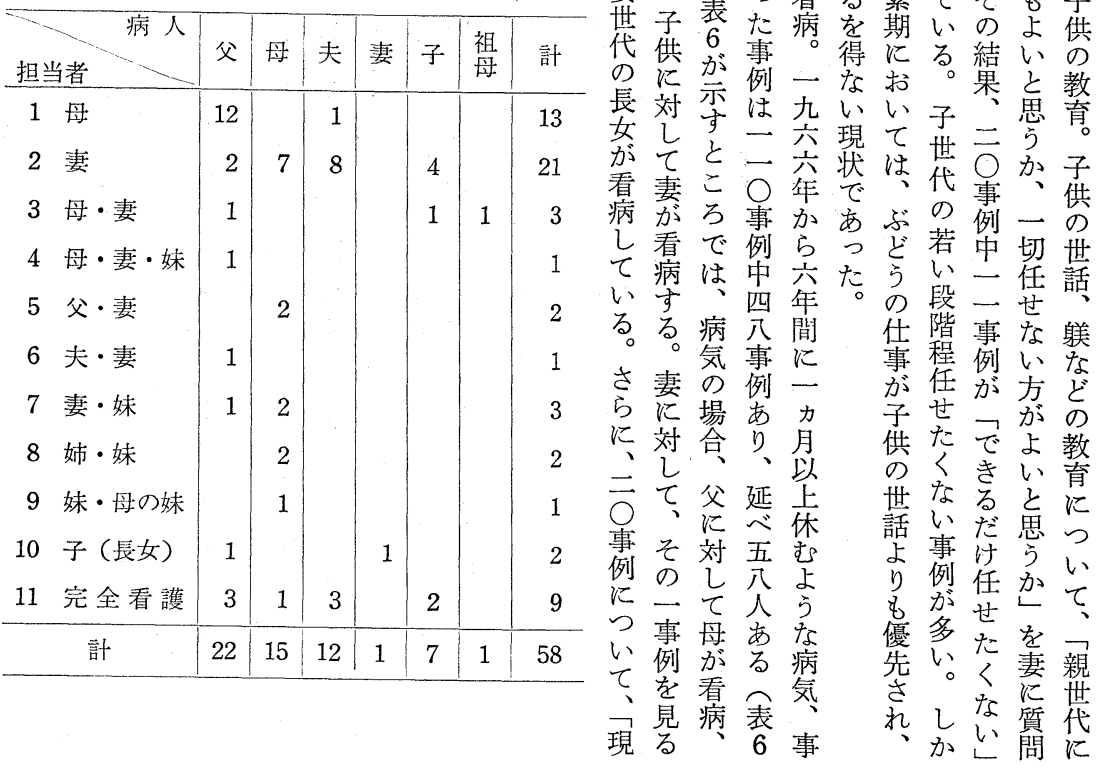

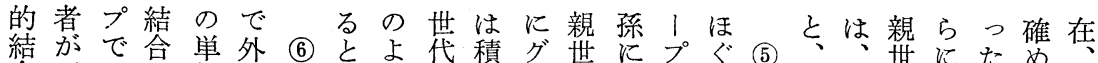



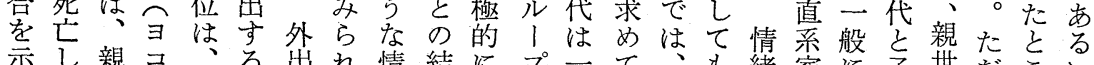

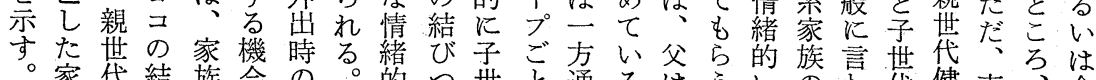
家代結族会の。的卫世之通る性方 族文合的要結、代に行。母人た強れ独在努心後

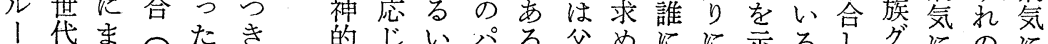

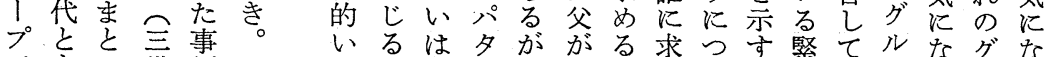

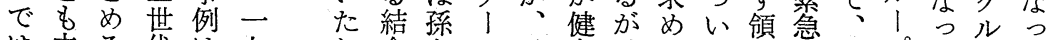

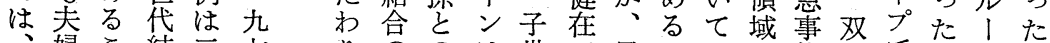

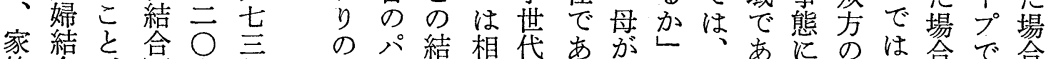

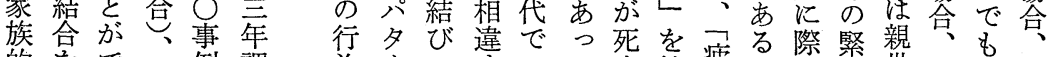

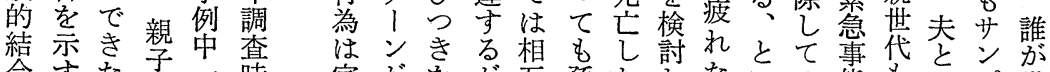
合志た結二時家がをが互棌たしたいの態をそプ世

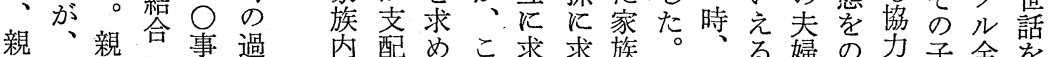

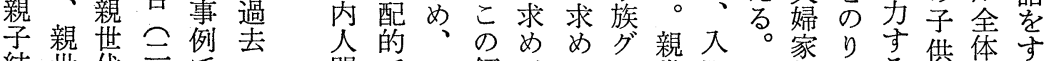
結世代正で間で一領ててル世浴族り 供体す 合代健䒫年関あ方域いい代時族气る。る

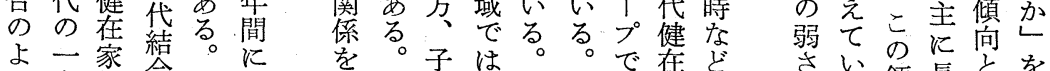

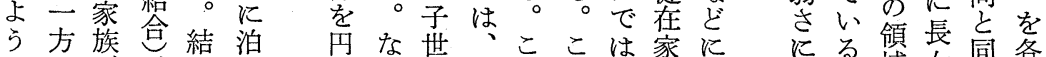
にのグ、びり滑打代親のの、族か、比。域女栭各

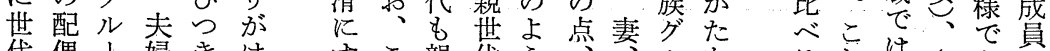

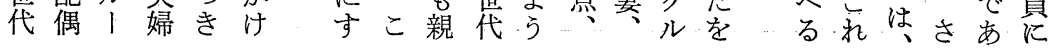


ここ現が逆あ

よ $T$ のつに文

う $\mathrm{V}$ 生

にを活て親ぎ

置をみ世の

親き観る代子

世、察とが供

代子等、ど夫

は世る父の婦

意代之、程に

識と、母度求

面 番 親と生め

に組世称

おの代に

小好性

て

分が盼れ学京

離違達に世る

にうのは代

対 場 部 否

乙合屋定分

て否別を的離

定々確あよ

的に保るう

でみ $\widehat{14}$ 。

あてししし

るいてかて

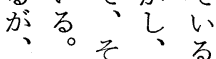

に上世互う依答事い○子が経う代以 与代援に存え例る事世多済かでの上2 つには助乙的てが。例代く的。は意の

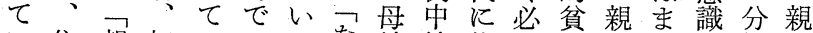
い住親相いはるな健健依要困世势喿析世 るま密互るな。る在在存々な代、併は代 ○いな依。いこべのでしなどは親せ核と と方親存し、のく二古よるが老世て想子

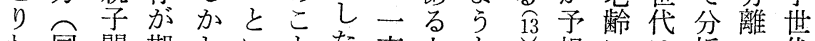
わ同関期しいとた事九と想には析の代 け居係待、えか方例事し之さと分さ実の

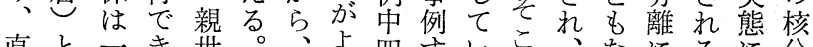

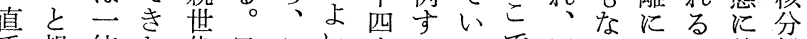
系親緒な代母父い事心゙るで周っ関衣着離 家密に心ははは冖例てか、囲てし貝に 族な住し父、依残がのに親の沶てょし関 で親まと母現存り马父つ世人こいりたす は子ないと资的三必はい代のるか明結る

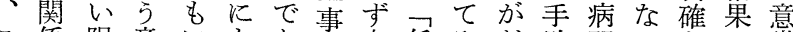
こ係限意にもあ例自任みど助弱るなで識 のをり識つ方分せょの快や意分あ よ同期が別若がう程や身識析る う待強居以、任し方。度身体をと。 な視でいす世母世たがこ身の的もなこ 親すき。れ代はた方よれの回不っるの 子るなすばにそ方がいに回り自てで実 の意いな親任れがよレよりの闪いあ態 相識しわ子せによいるるの世答るるる

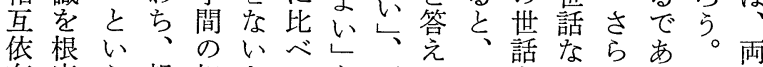
存底う親相よてと五て二皆どう方世
表 7 同，別居意識 (1972年)

\begin{tabular}{|c|c|c|c|}
\hline 意 識 成員別 & 夫 & 妻 & 計 \\
\hline 1 同居すべきである & 34.5 & 36.4 & 35.5 \\
\hline 2 別居すべきである & 32.7 & 29.1 & 30.9 \\
\hline 3 事情による & 25.5 & 29.1 & 27.3 \\
\hline 0 わからない & 5.5 & 4.5 & 5.0 \\
\hline 不 明 & 1.8 & 0.9 & 1.3 \\
\hline 計 (事例 $=110)$ & 100.0 & 100.0 & 100.0 \\
\hline
\end{tabular}

表 8 扶養意識 (1972年)

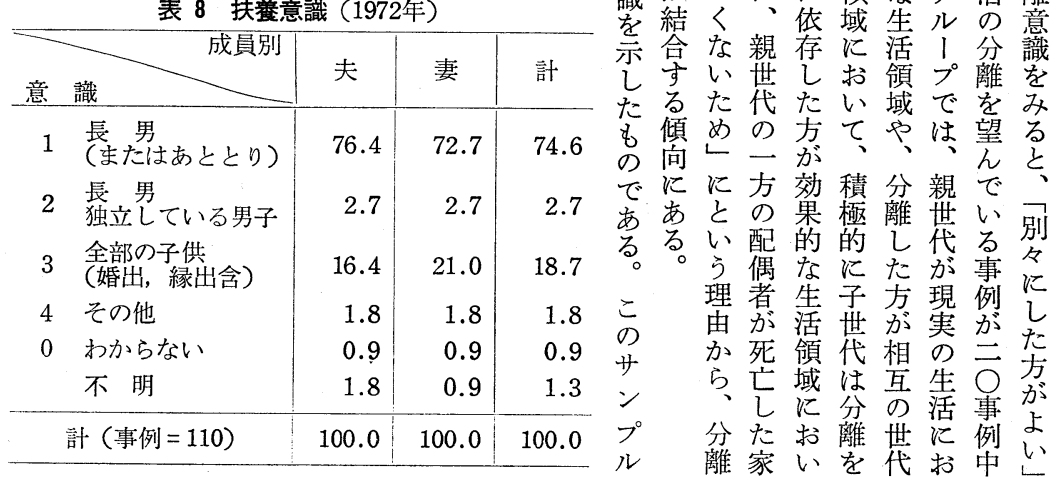

の族て求にい九 表傾グはめとて事部と実 7 向ル結るっ分例分この はの I 合。て離あ的万生 子あプを他楽しるあで活 世るで求方して。る次の 代領はめ好る親いに二 域、て子るプ世は、領 同で親い世よラ代全子域 \&親る代 らイ健面世河 別而かさ。は心在的代お 居世ささ相生 I家にのい 竟代み方互活卜族生分て 意出しに䕘なグ活離分 結く、依域生ルの意離 示合な親存に活 I 分識し しすい世しお領プ離をて たる代たい域でをみい

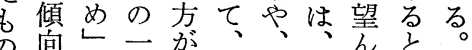
, 別 隹 L でにに方効積分親で 


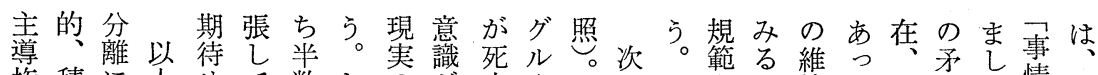

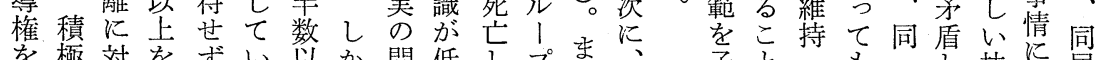

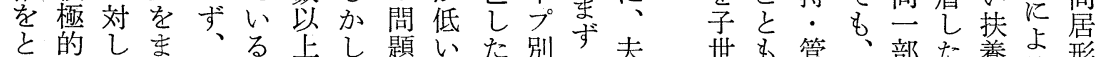

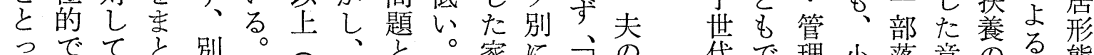

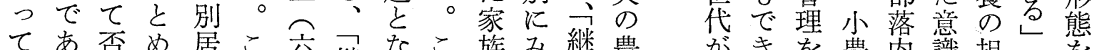

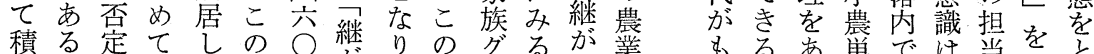

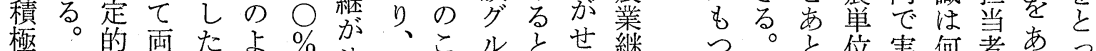

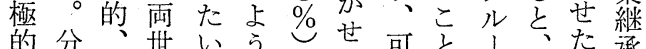

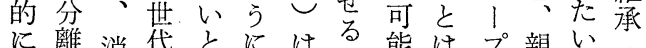
に離消代とにはる能はプ親い 分し極の望公老は性周父世家

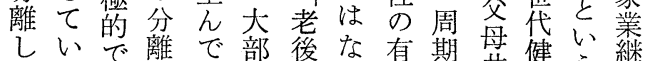
てるあにい分をい無段共在う䋖 い現る関るは子し㤎階死家意承 る実が夺事農供若答家族識の


活世識ご承と慮すずルザ

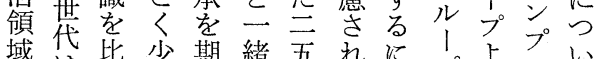
域は比少期緒五れにプよフいい をそ較な待に事てしてでり 中て るれすいし蓦例いた格交み 六対衣表おし三結っ継一七上 子し 親参り、た四果て継方三う 世て親参々い照そしで継せ配市表 帒肯代照そとのあ承た酯市表 つ。位実何者あっ 限こつの施汇はわて り、のぎ経さ求夫せ、 、よの営れめ水める なら子热てら妻々に 直農継なるるも半か 系業承わ共で長数か 制継すれ同亦男以わ 家承るて消亏を上ら 族家こい毒うあにず は家とる作かげな、 維業をた業。てる。別 持継期めのそいる居 存を资資要るを守 続省て産な因至かべ さ待い令部の表かき れ徆る生分一参わで るすた産的っ窯ら市 でる価手共は照す、る が定は。を主う万㤎者る。参

認打に

めいの 親

ててみ世

小身起代

るに因

でつし分

あけて 離

ろたいに

う価る 対 が、值のし

老規はでて

人範な定 福に心的 祉を 社るそ栖 会何—で 障人般市 制か般 る が老親 要 充人 世要 分は代は に夫がは 成婦旧個 熟家民人 己 族法の て 制 下 意 表 9 農業継承意識（1972年）

\begin{tabular}{|c|c|c|c|c|c|}
\hline 意識 グループ別 & 父母健在 & 父死亡 & 母死亡 & 父母死亡 & 計 \\
\hline 1 継がせたい & $\begin{array}{l}50 \\
(69.4)\end{array}$ & $\begin{array}{l}14 \\
(63.6)\end{array}$ & $\begin{array}{c}4 \\
(57.1)\end{array}$ & $\begin{array}{c}2 \\
(66.7)\end{array}$ & $\begin{array}{c}70 \\
(67.3)\end{array}$ \\
\hline 2 継がせる気なし & $\begin{array}{l}17 \\
(23.6)\end{array}$ & $\begin{array}{c}5 \\
(22.7)\end{array}$ & $\begin{array}{c}2 \\
(28.6)\end{array}$ & $\begin{array}{c}1 \\
(33.3)\end{array}$ & $\begin{array}{c}25 \\
(24.0)\end{array}$ \\
\hline 3 D.K. & $\begin{array}{c}5 \\
(6.9)\end{array}$ & $\begin{array}{c}3 \\
(13.6)\end{array}$ & $\begin{array}{c}1 \\
(14.3)\end{array}$ & & $\begin{array}{c}9 \\
(8.7)\end{array}$ \\
\hline 計 & $\begin{array}{c}72 \\
(100.0)\end{array}$ & $\begin{array}{c}22 \\
(100.0)\end{array}$ & $\begin{array}{c}7 \\
(100.0)\end{array}$ & $\begin{array}{c}3 \\
(100.0)\end{array}$ & $\begin{array}{c}104 \\
(100.0)\end{array}$ \\
\hline
\end{tabular}


た単極な

めに的 W

に伝、現

適 統 否 実

応的定に

表 10 「継がせる気がない」場合の同，別居意識（1972年）

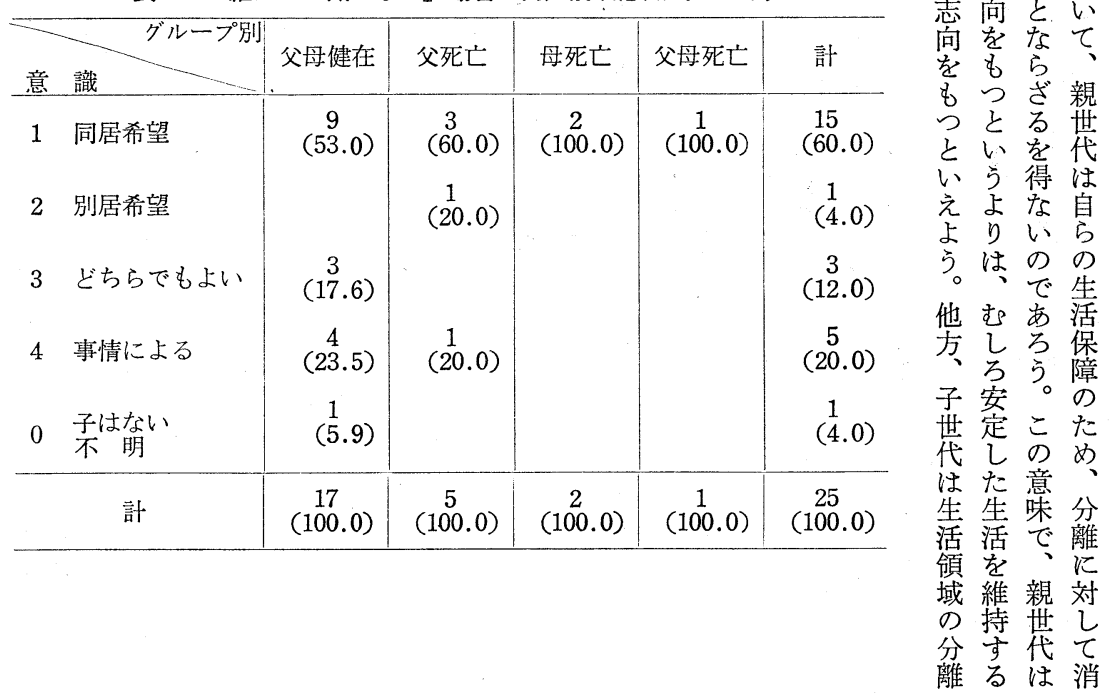

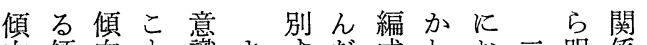
向傾向之識ま导だ成わお二明係本 を向をがのずる傾さらい世らの稿 示を示で両、比向れずて代かあは 寸示すき面核較ばる、、夫にり 生す生るか分的かこ親現婦な方動 活生活。ら離安りと世害同っを態 領活領そ観は定でか代と居た分的 域領域れ察生しはら, 意の点離分

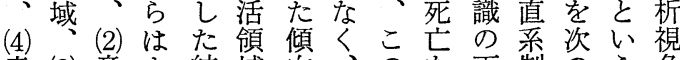
意 (3) 意ま結域向、の雷制のう角 識意識ず果にで家分契面家よ観を 面識面、、よ亦族離機で族う点導 も面で (1) そっる内傾に、はに架 現では現れて、部向、分、要ら、 実は結実らことのは家離限約捉 に分合にの規親直族のら拝直 打離しもあら定子系の傾れるた系 いすて意りの守両制役向たこ研制 てるい識方ある世家割を生と究家 もがる面はりこ代族構示活がで族 結、がに次方と間の造し領であに 合現、おの㤎がの不はつ域きるお を実現い四異で境安子つ域る。 示に実てつなき界定世あ家。以る すはにすにるる索代る族上両 す結 生合分離類現確华心に期分代

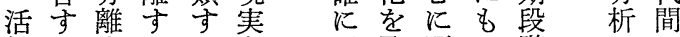
領る守るると文架再階加
と目すに実自や 称面留分同 五ここきと方農の別 々气消々業扶居 結でと極す継養意 あは的る承の識 万志。の問に

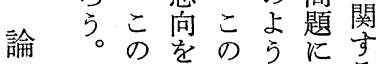
よ示よななる うすう家る世 な矛流文袋 矛盾、公 盾乙子世世離 した世代代に た面代的分対 志とは継離 乙 向を分承にて がも離に消は 、っ たお極積 どて対 い的極 の いして $と$ 的 よるて な肯 う。積強る定 にな極く。定 変お的直さ的 华、志系ら す今向制にる る後柰族現㤎 
が主い移さ役る

にと行せ割るか変ンは(1)

一生めさる集こ

般じせ。移団ろ

にるこ学文行的で

周

こ期が生うる割に

傾階きるは歩お核

向はる緊、手け分

は、か張そ前る離

三生らのれに分は

夫活で緩はお離家

婦領あ和親いの族

揃域る $る$ 世艺傾周

てょ関てかじは段

Wっ係效 ら、、階

るて的果子世親に

若必役を世帯世よ

いず割も代の代っ

段しにちへ役かて

階 \& $\supset$ 家 割 5 \&

に一心緊族交子そ

強定て張の代世の

いではを集を代㘯

○は、最団スへり

なな核少的么そ方

おか分限役、れが

つ離に割 ズ

参たがくをにのな

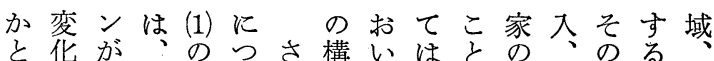
分し変個生いら造て目団っ掃なを かて化人活てにに見疲お戀く除らあ れいし用領、、拙労い方担ばげ てるた支域こ反いししてのい当、る いこに出にこ覆て得た見場も者そこ るとも金おで調維た時出汇の省れを こで出いは查持。の乙担夜ら㤎 あか所て、湟 $、$ 当具はで るおが、個よ存り高た V 者分、き

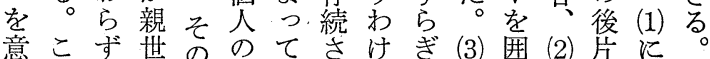

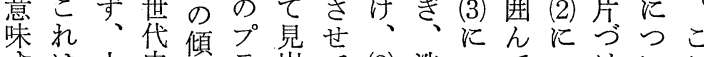
すは小中筒 ラ出て (3) 洗つでっけいこ る、遣心㤎イしい濯い過い、てで 小いか強バ得る(4) 淮でて小は示 遣のら悉シた。の看はしは遣、唆 い出子活七生病たた個さ の所世た、年活、子い親の人れ 出は代子個間領個供と先出部た 所両中c人见 加世心W的掠 世代へえ欲け 带分とる。求る の離、。充 核 財 晻そ注足分 布タの目に離 の 1 パす関の あンタべす浸 りヘけきる透
域人の し婦所屋限 が用教なと 直支育が子よ夫の 系出、少々婦生 制 金 躾、婦 、部 活 家の、別がき屋領 族出 (4) 々共用の域 を所ににに品設を 内、つ見 $\neg$ 置 列 部にいる—購と挙

らはっ要にし夫族 夫なた因はか婦周 婦く。至し制期の以生こ害采を婦調な成階、段あ察

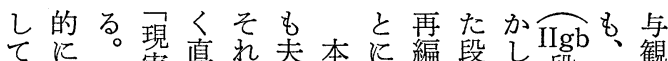
制ししして家的分る業のが家肯家查る。にこ階とに 家家たててそ族変析。をこか族定族の。統至れにっょ 族族がのいれへ化結取々観制的制サ合っらにぎつ

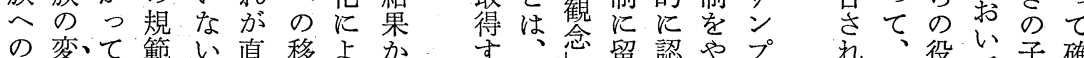
の変て範い直移よ吕 過形、、挐系行っ 渡に現制結制過て 言 期留在度局家程引艺 るのに族にきば あ現核変この打起 る象分化の類 汇こ㨁 いで離を分型るさ系 はあのも離変変れ制 両る傾たは化化る家 者。向ら家にの。族 がそは族直一そに 併こ家ま類接傾れお 存に族で型影向はけ す我ののの響とまる る々変分転をみた核 とは質離換与る、分 い、傾をえこ直離 わ直せ向せると系は れ系まををと製 る制る示るこで家主 現家現さ決乃き族に、 代族象な定ま方名 家かでか的で。ら家 る両 要めやル 過世意うな否で 程代識と方定は でが方ら的 選自のる、に一 び主変。現受般 之的化実讨㳊 らににりに止親 さ選即わ農め世 れび応け業て代 たとし、継いは 居って子承る 住たい世㤎現 制居な代扶、実 で住いに養子に あ制、つの世娄 るでこい問代意 こはとて題は識 そながは意面 にく指、な識に も摘夆る面お 起必で弿とでい 因然き態強はて
机役尔子確

る死割 、夫認 そを竞主婦し 乙契汀長之 て機る分子こ 纪分分肪 世三離離義で 代つは傾務は 的の家親向謷 非族世家殿世 連的代強笓代 続単のい文 な位一こと六 家の方委り五 族枠の䚋わ歳 㤎加配見わ以 連子偶出け上 さ代䇺得学で れ中死た校あ る心亡 。段 こ乞し階て 
え

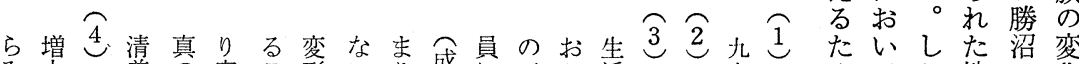

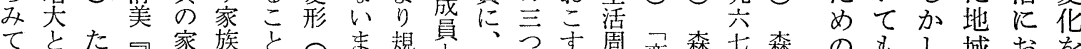

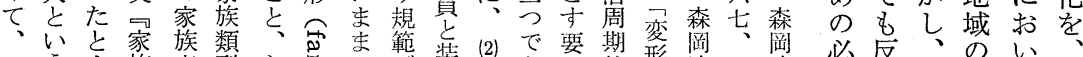

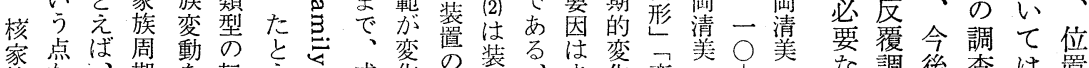

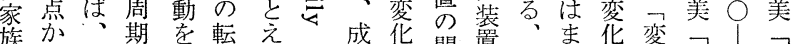

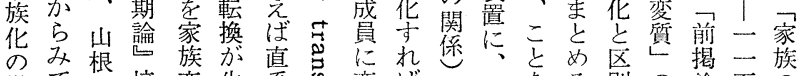

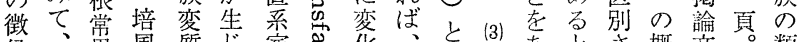

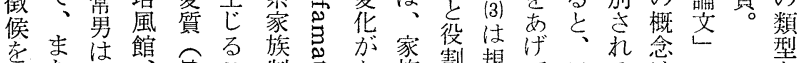

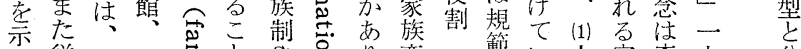

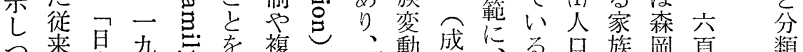

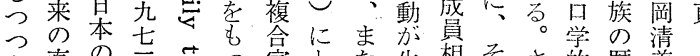
あ直の官家家た生相そさ的歴美

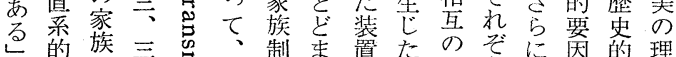
一拡の主家制ま置た関れ゙に因的理



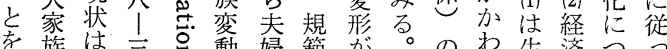

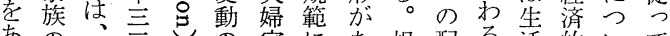

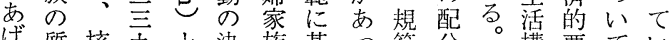
げ質核旮と決族基っ範分。構要てい て的家頁述定制苯たにに家造因之る。 る。化世照て要のなし条尔変要(3) の森 々带。几件変変て的る動素理変岡

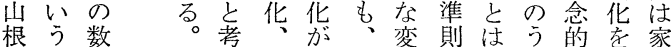
常点量 森えっ起家変則は所 5 的要家族 男吕的岡亦き族がつ有成图きの

作查後查は置 業を筆果以け で試者で上る あみがあのこ るるこり り よ 之ここ、う 言之で直にで うは提ち言き こ示に 5 。 方族た般京 で社よ化 が き会うさで る学なれき 合の観るる 現点 性 が 代格 的 $5 の こ$ 課、もれ 題他のは にのでご た地はく

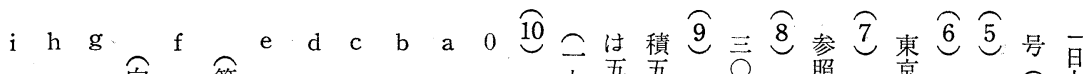
妻夫雪子第末第第第夫家九五吾全

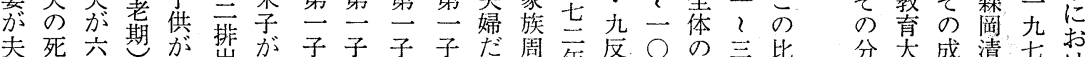

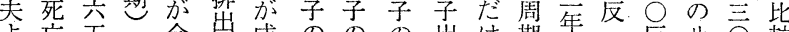

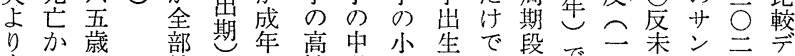

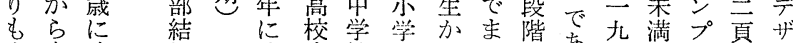
先妻達婚達卒校校らだの矢七のル老イ

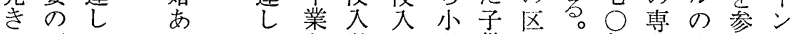
に死てるてか学学学供分年業中照は 死亡か加方名校加は辳少箖

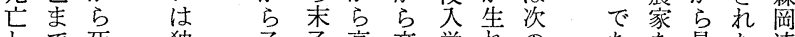
しで死独子高卒学机の㐫最た清

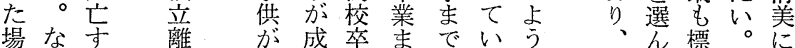

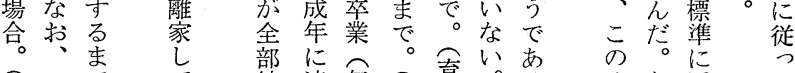

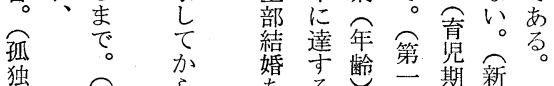



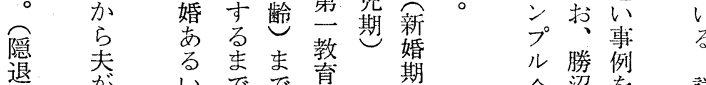

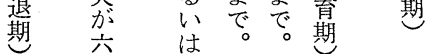

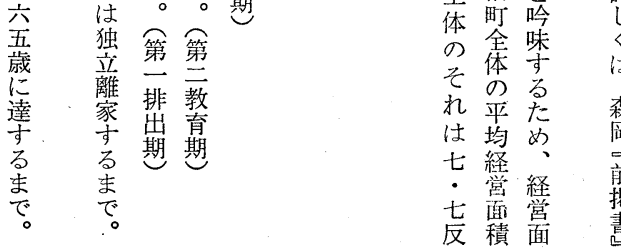

分希学荗清䒠计 は社と告る 、会气前三家 森学て提西族 清究森畫頁化 美室岡言照現

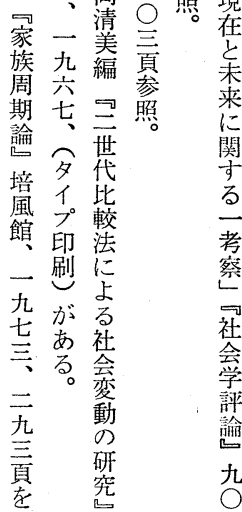




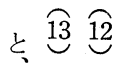

祖分分

代は隻

同居代森

乙 $の$ 相清

心互美

な援可

以助前

六関揭

○係畫

八つ

○い二

歳て四

ま 検 頁

で討 参

はて 照

校

でる

の 乙

点れ

でに

援 よ

（付表）対象農家の各成員別平均年齢

\begin{tabular}{|c|c|c|c|c|c|c|}
\hline & \multicolumn{3}{|c|}{ 1966年 } & \multicolumn{3}{|c|}{ 1972年 } \\
\hline & 平均年齢 & 人数 & 年齢幅 & 平均年齢 & 人数 & 年齢幅 \\
\hline 父 & 68.4歳 & 104人 & 85-54歳 & 73.0歳 & 79人 & 85-63歳 \\
\hline 母 & 64.5 & 104 & $83-52$ & 69.7 & 94 & $89-58$ \\
\hline 夫 & 36.9 & 104 & $45-31$ & 42.6 & 104 & $51-39$ \\
\hline 妻 & 33.1 & 104 & $45-24$ & 88.7 & 104 & $51-30$ \\
\hline
\end{tabular}

育拉帒林

学対專岡のI、

、象業美市 II

高震の고

橋芜父前

子各の書注

氏 成業密

主二核

烈平分家

均年 $\bigcirc$ 族

年 齢 三 数

齢六公老

付七頁

表歳参照中

参兼照孝

照

の の

こ学

。杭

こ

分歳

析 で

はあ

東る

京な

III

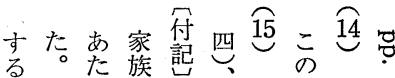

क 专? 专

次まつ部

地勝

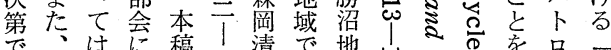

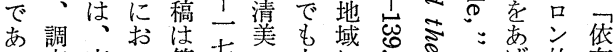

る查東心筆七㫐有に

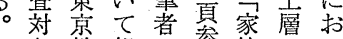

象教報奛族に心

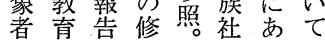

㐭大要坚

会る隱

方学息要

学た居

に森旨の 現で㤎古

のめ 制

お清、部

東
京
都
充
学
大
学
院
蒱
課
程

代あお

的るこ

世美加で

話 教 筆 あ

に授修り

題 注わ

なに正第

た始た四

ᄂ 2 れ

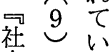

。終它七

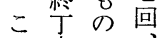

こ寧 で

にな早

咸御る。社

感塮導 本 会

の莸稿学

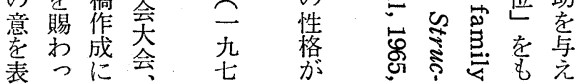

会参な

学照怘

可的存

㕸地

胥る位

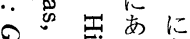

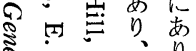

\&

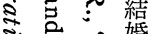

ฐ

总空㞭代

的巷西

影击代

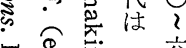

論

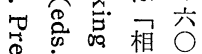

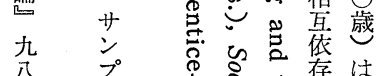

密宫的援 
structure of the family.

It is often said that families in Japan are in a transitional period from the long-established stem family to a modified one or even to a variant of nuclear family. Stem families are varied in their internal structural patterns; in some families than in others parent-couples are more sharply separated from childcouples in the sphere of residence and/or family budget. The data of the present study are drawn from the field interviewings three times in Katsunumachō, Yamanashi-prefecture: first in 1966, second in 1972, and finally in 1973. Consequently, both a cross-sectional analysis and a congitudinal analysis were applied to the data.

The findings will be summarized as follows:

1) The degree of separation of nuclear units within a stem family is on the increase. Privacy and satisfaction of personal needs are pursued largely as a result of the increasing separation of nuclear units.

2) A relatively marked separation of nuclear units takes place in the early stage of the life cycle of child's family of procreation. In such samples, however, separation of nuclear units is a function of development in the life cycle stage of a stem family.

3) The phenomenon of separation of nuclear units observed within a stem family does not represent family TRANSMUTATION (change in type), but remains family TRANSFORMATION (change in form).

\section{Max Weber's Recognition to Modern Ages}

- In Conformity with the Idea of die Versachlichung -

\section{Satoshi Yokoyama \\ Tohoku University}

This article is an attempt to grasp Weber's recognition to modern ages. In this article, I am concerned with the conception of die Versachlichung, because this conception seems to be useful when we examine Weber and Marx on their theories of modern ages.

My analysis consists of the following points.

1. According to Weber, that believers in Protestantism denied to deify creatures was a decicive factor in forming the capitalistic spirit. Thus, die persönliche Verhältnisse was broken through, and they selected the rational vocational labour as the calling. Such labour is equal to actions based on rules of the things (die sachliche Stellung), and results in die sachliche Verhältnisse. 


\section{The Epistemological Model of the Structuralism in Claude Lévi-Strauss}

\section{Chizuko Ueno}

Kyoto University

In 'Anthlopologie structurale' written by Claud Lévi-Strauss in 1958, he gives a certain 'conscious structure' of his structuralism, which seems to be distant from his 'unconscious structure' given in his actual analysis. His concept of 'structure', as Piaget says, should be accepted as a 'model' which is more consistent and more intelligible. From this viewpoint, we need neither admit the transcendentalism of unconsciousness nor deny the diachronic development of structures so as to be a structuralist. Then his dualism of 'ordres conçues' and 'ordres vécues' shold also be considered not as the equivalence of Marxist's dualism but as that of sign-evolutionist's stratification model, which is inspired from his own proposal that 'faits sociaux' are approached 'comme des signes'. At the former standpoint, the upper structure is partial and probable projection of the lower one; to the contrary, at the latter standpoint, the meta-structure is the wider and more general synthesis of its sub-structures, as 'l'ordre des ordres'. Sub-structure is literally 'sub', that is, partial.

In conclusion, his method is characterized by the three points; the stratification model of society, isomorphism among the stratified structures, and systematic approach to them. The current of the structuralism is thus understood to be the best fruit of western rationalism since Thomas.

\section{An Analysis of Separation of Nuclear Units within}

\section{a Stem Family in a Rural Community}

\section{Masae Yamamura Tokyo Kyoiku University}

The aim of this study is to clarify the relation between the two couples in succeeding generaiion within a stem family. The existing discussions suggest that a changing direction of stem families will be specified by studying the extent to which nuclear units are separated to each other in the role 